\title{
Študij polarnosti verig različnih viroidov in njihovih kombinacij pri okuženih rastlinah hmelja
}

\author{
Andrej SEČNIK ${ }^{1}$, Sebastjan RADIŠEK ${ }^{2}$, Nataša ŠTAJNER ${ }^{1}$, Jernej JAKŠE ${ }^{1,3}$ \\ Received October 30, 2019; accepted February 12, 2020. \\ Delo je prispelo 30. oktobra 2019, sprejeto 12. februarja 2020.
}

\begin{abstract}
Študij polarnosti verig različnih viroidov in njihovih kombinacij pri okuženih rastlinah hmelja

Izvleček: Hmelj (Humulus lupulus L.) je pomembna kmetijska rastlina, ki jo pridelujemo zaradi hmeljnih storžkov, ki so osnovna sestavina pri proizvodnji piva. Hmelj pa je tudi gostiteljska rastlina štirim različnim viroidom. V naši raziskavi, kjer smo želeli proučiti naravo okuževanja s strani viroidov, smo analizirali nivo akumulacije in polarnost verig molekul viroidov. S podatki RNK sekvenciranja smo pokazali, da se viroidi $\mathrm{v}$ rastlini razmnožijo do ravni zasičenja, kar kaže na biološko kapaciteto rastline. Negativne spremembe na ravni akumulacije posameznih viroidov med vzorci hmelja $\mathrm{z}$ enojno, dvojno ali trojno okužbo kažejo na to, da je med viroidi prisoten antagonizem, pri čemer je viroid razpokanosti skorje agrumov najmanj, viroid zakrnelosti hmelja pa najbolj občutljiv na ostala dva. Kar se tiče polarnosti viroidne RNK molekule pa podatki RNK sekvenciranja kažejo, da je v povprečju več (-) oblik kot (+) oblik viroida. Pri tem najbolj izstopa viroid razpokanosti skorje agrumov. Pri rezultatih obratne transkripcije in verižne reakcije s polimerazo v realnem času pa glede polarnosti zaznamo variabilnost med različnimi kombinacijami okužb, razen v primeru viroida razpokanosti skorje agrumov, kjer se podatki o polarnosti skladajo s podatki RNK sekvenciranja.

Ključne besede: hmelj; viroidi; RT-qPCR; NGS; RNK sekvenciranje
\end{abstract}

Studying strands polarity of different viroids and their combinations in infected hop plants

Abstract: Hop plant (Humulus lupulus L.) is an important industrial crop, grown for harvesting hop cones however, it is a host to four different viroids as well. The nature of viroid infections is not entirely clarified. In our work, we focused on analyzing viroid accumulation and their strands polarity through RNA sequencing and reverse transcription polymerase chain reaction in real time. RNA-seq data indicate that viroids amplify until saturation further demonstrating plant's biological capacity. Negative fold changes in accumulation of individual viroids between hop samples with single and multiple infections are suggesting an antagonistic relationship amongst viroids, where citrus bark cracking viroid seems to be the least and hop stunt viroid the most sensitive to the other two. RNA-seq data also show that on average (-) viroid strand is dominating over (+), especially for the citrus bark cracking viroid. Reverse transcription polymerase chain reaction in real time results from strand polarity analysis seem to be less consistent between different combinations of infection but are showing level of conformity with RNA-seq in the case of citrus bark cracking viroid.

Key words: hop plant; viroids; RT-qPCR; NGS; RNA sequencing

1 Univ. v Ljubljani, Biotehniška fakulteta, Oddelek za agronomijo, Ljubljana, Slovenija

2 Inštitut za hmeljarstvo in pivovarstvo, Žalec

3 Korespondenčni avtor, e-naslov: jernej.jakse@bf.uni-lj.si 


\section{UVOD}

Hmelj (Humulus lupulus L.) je pomembna kmetijska rastlina, ki jo gojimo zaradi hmeljnih storžkov. Ti se najpogosteje uporabljajo v pivovarstvu, učinkovine pa imajo tudi zanimive farmacevtske učinke. Hmelj napadajo različni patogeni mikroorganizmi, med njimi tudi štirje različni viroidi: viroid zakrnelosti hmelja (angl. hop stunt viroid, HSVd), hmeljev latentni viroid (angl. hop latent viroid, HLVd), viroid grbavosti jabolk (angl. apple fruit crinkle viroid, AFCVd) in nedavno potrjen viroid razpokanosti skorje agrumov (angl. citrus bark cracking viroid, CBCVd). Slednji na hmelju povzroča zakrnelost in odmiranje rastlin, zaradi česar so ukrepi na področju obvladovanja viroidnih okužb še toliko nujnejši. Poznavanje molekularnih mehanizmov rastlinske patologije je ključno za razvoj obrambnih strategij rastlin, zato smo v delu raziskovali naravo različnih kombinacij okužb viroidov HLVd, HSVd in CBCVd, pri čemer smo se osredotočili na analizo na ravni pomnoževanja viroidov v rastlinah in polarnosti molekul viroidov.

Viroidi so majhne, enoverižne molekule RNK z izrazito sekundarno strukturo, ki ne kodirajo nobenih proteinov (Diener, 1971), zaradi česar morajo za svoje biološke funkcije izkoristiti gostiteljeve molekule (Steger \& Riesner, 2003). Njihov genom je dolg med 246 in 401 nukleotidi (Flores et al., 2005). Viroidi hmelja so pripadniki družine Pospiviroidae, za katere je značilna paličasta struktura molekule RNK in to, da podvojevanje poteka v jedru rastlinske celice (Flores et al., 2017). Po rastlini se širijo sistemsko in povzročajo bolezenska znamenja, ki so značilna tudi za virusne bolezni (Góra-Sochacka, 2004). Viroidi iz družine Pospiviroidae se podvojujejo na način kotalečega se kroga, po asimetrični poti, kjer se tvorijo dolgi multimeri negativnih (-) verig, ki se prepišejo v dolge multimere pozitivnih (+) verig. Monomerne oblike viroidov pa posledično nastanejo $s$ cepitvijo dolgih multimernih $(+)$ verig. Sledi tvorba zrele krožne monomerne molekule, ki je zadnji korak v podvojevanju.

Viroid zakrnelost hmelja (HSVd) so prvič odkrili pri hmelju na Japonskem (Sasaki \& Shikata, 1977). Poleg hmelja okužuje tudi ostale rastline predvsem iz rodov $V i$ tis, Citrus in Prunus (Kofalvi et al., 1997). O hmeljevem latentnem viroidu (HLVd) so prvi poročali Puchta et al. (1988). Za okužbo hmelja s tem viroidom je značilno, da ne povzroča hudih bolezenskih znamenj, vpliva pa na vsebnost nekaterih metabolitov $\mathrm{v}$ hmeljnih storžkih (Barbara \& Adams, 2003). V slovenskih nasadih hmelja so Jakše et al. (2015) z uporabo tehnologije sekvenciranja naslednje generacije nedavno potrdili še okužbo $\mathrm{z}$ viroidom razpokanosti skorje agrumov (CBCVd). Duran-Vila \& Semancik (2003) sta ga opisala kot himernega rekombinanta med vrstama viroid agrumov eksokortis (angl. citrus exocortis viroid, CEVd) in HSVd, kar bi tudi pojasnjevalo njegovo sposobnost okužbe hmelja (Jakše et al., 2015). Za omenjene viroide še ni bilo pokazano, da se prenašajo z vektorjem (Duran-Vila \& Semancik, 2003), kar pomeni, da je v njihovo širjenje najverjetneje vpleten človek oz. agrotehnični ukrepi. Zaradi tega je za njihovo obvladovanje potrebno sledenje dobri kmetijski praksi, kar največkrat vključuje razkuževanje delovne opreme in orodja ter prilagojena agrotehnika pridelave. Za preprečevanje in omejevanje širjenja okužbe med rastlinami pa je nujno odstranjevati okužene rastline ali okužene dele nasadov in ponovno saditi zdrav sadilni material.

\section{MATERIAL IN METODE}

\subsection{BIOINFORMATSKA ANALIZA}

V raziskavi smo izvedli bioinformatsko analizo podatkov RNK sekvenciranja, ki smo jih pridobili v sklopu projekta "Analiza odziva rastlin ob hkratnih okužbah viroidov in identifikacija odpornosti - L4-6809«, ki sta ga izvedli sodelujoči organizaciji Inštitut za hmeljarstvo in pivovarstvo Slovenije in Oddelek za agronomijo, Biotehniška fakulteta, Univerza v Ljubljani. Sekvenciranje RNK je bilo izvedeno s tehnologijo Ion Torrent. Sekvenčne podatke, ki so dostopni preko SRA arhiva (bioprojekt s pristopno številko PRJNA528793) smo obdelali s programoma CLC Genomics Workbench (različica 12) in CLC Genomics Server (različica 11), kjer smo sledili standardni obravnavi sekvenčnih podatkov RNK sekvenciranja, začenši s kontrolo kakovosti odčitkov, s katero smo preverili skupno število odčitkov, njihovo dolžinsko razporeditev, vsebnost GC, morebitno nedoločitev baz (angl. ambiguity) in razporeditev kakovosti (angl. PHRED quality score). Za izvedbo smo uporabili orodje »QC for Sequencing Reads«. V drugem koraku smo filtrirali (angl. trimming) surove odčitke po dolžini tako, da smo zavrgli vse odčitke, ki so bili krajši od $35 \mathrm{bp}$. Izvedli smo tudi filtriranje po kakovosti z vrednostjo 0,05 in odstranili adapterska zaporedja tehnologije sekvenciranja Ion Torrent. $\mathrm{V}$ ta namen smo uporabili orodje »Trim Reads«. Na očiščenih zaporedjih smo ponovili kontrolo kakovosti in s tem dobili kakovostne odčitke, ki smo jih v nadaljevanju uporabili za kartiranje na referenčne genome viroidov, ki imajo v podatkovni zbirki NCBI naslednje pristopne številke: HLVd - NC_003611, CBCVd - KM211547 in HSVd - NC_001351. Uporabljena zaporedja so $\mathrm{v}$ analizi popolnoma enaka zaporedjem uporabljenim pri okuževanju rastlin $\mathrm{z}$ umetnimi kloniranimi konstrukti viroidov. Za kartiranje smo uporabili orodje "RNA-Seq Analysis«, kjer smo izpostavili tudi pozitivno orientiranost odčitkov. Na koncu smo izvedli 
še statistični test »Empirical Analysis of DGE«, ki temelji na negativni binomski porazdelitvi podatkov RNK sekvenciranja. Za grafični prikaz rezultatov pa smo odčitke normalizirali z metodo RPKM (angl. Reads Per Kilobase of transcript, per Million mapped reads) (Mortazavi et al., 2008).

\subsection{ANALIZA Z OBRATNO TRANSKRIPCIJO IN VERIŽNO REAKCIJO S POLIMERAZO V RE- ALNEM ČASU}

Vzorce hmelja okuženega z različnimi kombinacijami viroidov smo ravno tako pridobili iz prej omenjenega projekta, rastline so bile vzorčene 28 mesecev po inokulaciji. Različni biološki vzorci pomenijo različna obravnavanja hmelja oz. okužbo z različnimi kombinacijami viroidov. Te so [1] = HLVd, [2] = CBCVd, [3] = HSVd, [4] $=$ HLVd + CBCVd, [5] = HLVd + HSVd, [6] = CBCVd + HSVd in [7] = HLVd + CBCVd + HSVd. Vsako biološko obravnavanje smo testirali $\mathrm{v}$ treh bioloških ponovitvah. Izolacijo skupne RNK smo izvedli z uporabo komercialnega kita Spectrum ${ }^{\text {Tw }}$ Plant Total RNA Kit (Sigma-Aldrich), po navodilih proizvajalca. Po izolaciji smo z napravo NanoVue spectrophotometer (GE Healthcare Life Sciences) izmerili koncentracijo RNK in ocenili njeno čistoto. Razgradnjo molekul RNK smo ocenili na podlagi vrednosti RIN, ki smo jih določili z napravo Agilent Bioanalyzer 2100 (Agilent Technologies). Za oceno ravni pomnoževanja viroidov smo izvedli RT-qPCR v dveh korakih. Za oba koraka smo uporabili začetne oligonukleotide, ki so jih zasnovali Matoušek et al. (2017) in so prikazani v Preglednici 1, njihovo zaporedje pa je zapisano v orientaciji od 5' proti 3'. V prvem koraku smo izvedli obratno transkripcijo molekul viroidov tako, da smo specifično prepisali ali (+) ali (-) verige viroidov. Uporabili smo komercialni kit SuperScript ${ }^{\text {tw }}$ IV First-Strand cDNA Synthesis Reaction (ThermoFischer) in sledili priloženemu protokolu. Pred izvedbo protokola smo izvedli denaturacijo sekundarnih struktur viroidov s 4 minutno inkubacijo pri temperaturi $98^{\circ} \mathrm{C} . \mathrm{Z}$ namenom relativne kvantifikacije okužbe smo pri vseh bioloških ponovitvah izmerili še nivo izražanja gena s konstantnim izražanjem, DRH1 (Štajner et al., 2013). V tem primeru smo za sintezo cDNK uporabili komercialni kit High-Capacity cDNA Reverse Transcription Kit (Applied Biosystems).

$\mathrm{V}$ drugem koraku pa smo izvedli qPCR z uporabo Fast SYBR ${ }^{\circ}$ Green Master Mix-a (Applied Biosystems) na napravi Applied Biosystems 7500 Fast Real-Time PCR System, pri čemer smo uporabili par začetnih oligonukleotidov specifičnih za prepisani $(+)$ ali $(-)$ verigi posameznega viroida oz. za gen DRH1. Program pomnoževanja je bil sestavljen iz več faz. Začetni denaturaciji $20 \mathrm{~s}$ pri temperaturi $95^{\circ} \mathrm{C}$, je sledilo 40 ciklov $3 \mathrm{~s}$ pri temperaturi $95^{\circ} \mathrm{C}$ in $30 \mathrm{~s}$ pri temperaturi $60^{\circ} \mathrm{C}$. Na koncu je sledila še analiza talilnih krivulj, pri čemer je prvi korak trajal $15 \mathrm{~s}$ pri temperaturi $95^{\circ} \mathrm{C}$, drugi korak 60 s pri temperaturi $60^{\circ} \mathrm{C}$, tretji korak $15 \mathrm{~s}$ pri temperaturi $95^{\circ} \mathrm{C}$ in zadnji $15 \mathrm{~s}$ pri temperaturi $60^{\circ} \mathrm{C}$. Na podlagi matematičnega modela (Pfaffl, 2012) smo izračunali relativne nivoje izražanja tarčnih genov $\mathrm{z}$ namenom, da smo lahko med seboj primerjali ravni akumulacije viroidov med različnimi biološkimi obravnavanji. Vrednosti Cq smo izmerili na istih vzorcih za posamezne viroide in za gen DRH1 s konstantnim izražanjem. Najprej smo iz dobljenih vrednosti Cq izračunali povprečje bioloških ponovitev, nato pa nadaljevali izračun relativnega izražanja z metodo $\Delta \Delta$ Cq. Dobljene vrednosti smo uporabili za grafični prikaz. Glede na lastnosti pridobljenih podatkov poskusa smo za statistično testiranje uporabili robusten test ANOVA, ki na podlagi t-testa preverja ali sta povprečij dveh ali več populacij enaki. Zanj smo uporabili programski paket $\mathrm{R}$ (paket Rcmdr, različica 2.4-x).

\section{$3 \quad$ REZULTATI IN DISKUSIJA}

\subsection{NIVO POMNOŽEVANJA VIROIDOV V VZOR- CIH HMELJA}

Rezultati filtriranja odčitkov so predstavljeni v Preglednici 2. Analiza je pokazala veliko kakovost surovih

Preglednica 1: Zaporedja začetnih oligonukleotidov uporabljenih v RT-qPCR v orientaciji 5'-3' Table 1: Primer sequences used in RT-qPCR in 5'-3' orientation

\begin{tabular}{llll}
\hline & Viroid & Vodilni začetni oligonukleotid & Komplementarni začetni oligonukleotid \\
\hline RT prepis & HLVd & ATCCCTCTTCGAGCCCTTGCCAC & GGATCCCCGGGGAAACCTACTCG \\
& CBCVd & GATCCCTCTTCAGGTATGTTCCCTCCTC & GGATCCCCGGGGAAATCTCTTCAG \\
& HSVd & GGCTCCTTTCTCAGGTAAGTCTCCTCCC & GGAGCCCCGGGGCAACTCTTCT \\
\hline qPCR & HLVd & CGGCGACCTGAAGTTGCT & TTCCAACTCCGGCTGGTGT \\
& CBCVd & TCACTGGCGTCCAGCACC & AGGAAGAAGCGACGATCGG \\
& HSVd & CGGTGCTCTGGAGTAGAGGC & GTGATGCCACCGGTCGC \\
\hline
\end{tabular}


Preglednica 2: Povzetek rezultatov filtriranja NGS podatkov. Prikazani so podatki za povprečno število odčitkov, povprečno število nukleotidov in povprečno dolžino odčitkov na vzorec, pred in po filtriranju. Podatki so urejeni po bioloških obravnavanjih

Table 2: Summary of NGS data filtering showing average number of reads, average number of nucleotides and average read lengths per sample before and after trimming. Data are summarized according to biological treatments

\begin{tabular}{|c|c|c|c|c|c|c|}
\hline \multirow[t]{2}{*}{ Vzorec } & $\begin{array}{l}\text { Število } \\
\text { odčitkov }\end{array}$ & $\begin{array}{l}\text { Število } \\
\text { nukleotidov } \\
{[\mathrm{Gb}]}\end{array}$ & $\begin{array}{l}\text { Povprečna } \\
\text { dolžina } \\
\text { odčitkov [bp] }\end{array}$ & $\begin{array}{l}\text { Število } \\
\text { odčitkov }\end{array}$ & $\begin{array}{l}\text { Število } \\
\text { nukleotidov } \\
{[\mathrm{Gb}]}\end{array}$ & $\begin{array}{l}\text { Povprečna } \\
\text { dolžina } \\
\text { odčitkov [bp] }\end{array}$ \\
\hline & \multicolumn{3}{|c|}{ Pred filtriranjem } & \multicolumn{3}{|c|}{ Po filtriranju } \\
\hline [1] = HLVd & 30.054 .574 & 3,2 & 105,6 & 27.398 .618 & 3,1 & 111,4 \\
\hline$[2]=\mathrm{CBCVd}$ & 31.566 .534 & 3,5 & 110,9 & 29.511 .262 & 3,4 & 115,9 \\
\hline$[4]=\mathrm{HLVd}+\mathrm{CBCVd}$ & 21.152 .456 & 2,1 & 99,5 & 20.288 .798 & 2,0 & 100,8 \\
\hline [7] $=\mathrm{HLVd}+\mathrm{CBCVd}+\mathrm{HSVd}$ & 23.860 .218 & 2,6 & 109,7 & 23.339 .936 & 2,6 & 110,4 \\
\hline
\end{tabular}

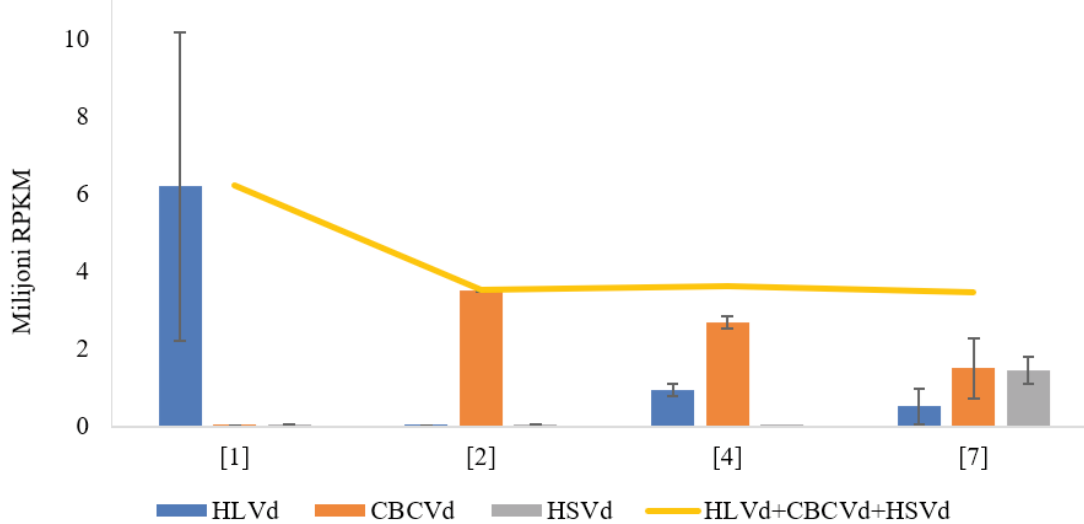

Slika 1: Raven akumulacije viroidov na osnovi NGS analize pri različnih bioloških vzorcih. [1] = HLVd; [2] = CBCVd; [4] = HLVd in CBCVd; [7] = HLVd, CBCVd in HSVd. Rumena linija predstavlja seštevek vrednosti RPKM vseh treh viroidov. Intervali na stolpcih predstavljajo standardne odklone

Figure 1: NGS data showing viroid accumulation within different biological samples. [1] = HLVd; $[2]=$ CBCVd; $[4]=$ HLVd and CBCVd; [7] = HLVd, CBCVd and HSVd. Yellow line represents the sum of RPKM values of all three viroids. Intervals on the columns indicate standard deviation

Preglednica 3: Povzetek rezultatov testa EDGE za raven akumulacije posameznih viroidov Table 3: Summary of EDGE test results for individual viroid accumulation

\begin{tabular}{lllll}
\hline Viroid & Kombinacija okužbe 1 & Kombinacija okužbe 2 & Faktor spremembe & p-vrednost \\
\hline HLVd & HLVd & HLVd+CBCVd & $-1,29$ & 0,11 \\
& HLVd & HLVd+CBCVd+HSVd & $-3,11$ & 0,61 \\
& HLVd+CBCVd & HLVd+CBCVd+HSVd & $-1,28$ & 0,84 \\
\hline CBCVd & CBCVd & HLVd+CBCVd & 1,02 & 0,9 \\
& CBCVd & HLVd+CBCVd+HSVd & $-1,11$ & 0,35 \\
& HLVd+CBCVd & HLVd+CBCVd+HSVd & $-1,4$ & 0,1 \\
\hline
\end{tabular}

podatkov. Vrednosti RPKM so prikazane na Sliki 1 in odražajo raven akumulacije viroidov pri različnih vzorcih analiziranih z NGS pristopom. Rezultate qPCR analize vzorcev hmelja pa smo pretvorili v relativne vrednosti tako, da lahko različne ravni akumulacije primerjamo med različnimi vzorci. Relativne vrednosti qPCR analize za različne vzorce hmelja so predstavljene na Sliki 2.

Iz grafa na Sliki 1 (NGS analiza) vidimo, da se skupna količina viroidov (rumena linija) skoraj ne spreminja med različnimi vzorci. To smo potrdili tudi s stati- 


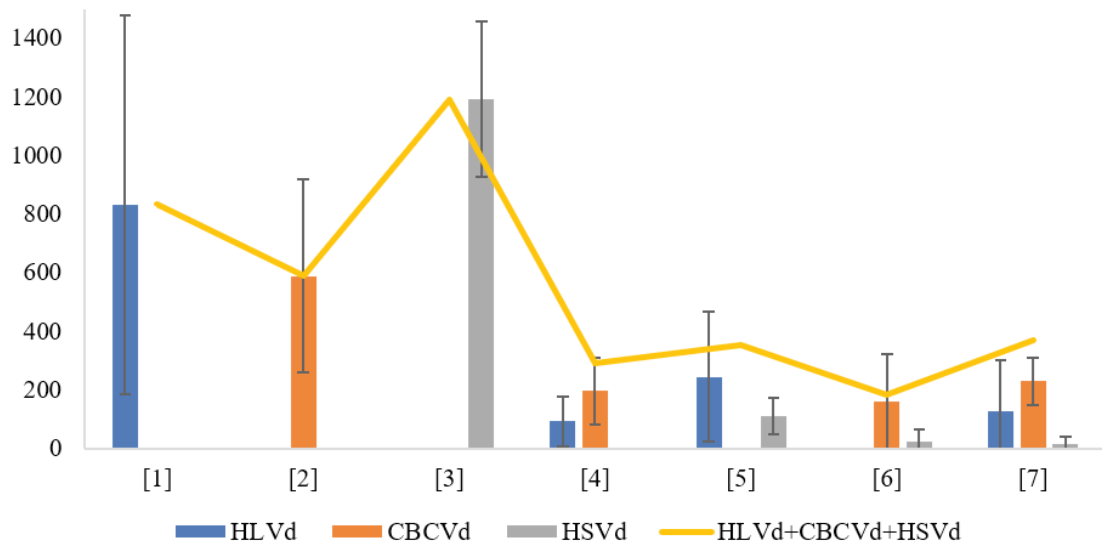

Slika 2: Raven akumulacije viroidov na osnovi RT-qPCR analize pri različnih bioloških vzorcih. [1] = HLVd; [2] = CBCVd; [3] = HSVd; [4] = HLVd in CBCVd; [5] = HLVd in HSVd; [6] = CBCVd in HSVd; [7] = HLVd, CBCVd in HSVd. Rumena linija predstavlja seštevek relativnih vrednosti ravni akumulacije vseh treh viroidov. Intervali na stolpcih predstavljajo standardne odklone

Figure 2: RT-qPCR data showing viroid accumulation within different biological samples. [1] $=\mathrm{HLVd}$; $[2]=\mathrm{CBCVd}$; $[3]=\mathrm{HSVd}$; [4] = HLVd and CBCVd; [5] = HLVd and HSVd; [6] = CBCVd and HSVd; [7] = HLVd, CBCVd and HSVd. Yellow line represents the sum of relative quantities of all three viroids. Intervals on the columns indicate standard deviations

Preglednica 4: Povzetek rezultatov testa ANOVA za raven akumulacije posameznih viroidov Table 4: Summary of ANOVA test results for individual viroid accumulation

\begin{tabular}{|c|c|c|c|c|}
\hline Viroid & Kombinacija okužbe 1 & Kombinacijaokužbe 2 & Faktor spremembe & p-vrednost \\
\hline \multirow[t]{6}{*}{ HLVd } & HLVd & $\mathrm{HLVd}+\mathrm{CBCVd}$ & $-9,04$ & 0,15 \\
\hline & HLVd & HLVd+HSVd & $-3,41$ & 0,89 \\
\hline & HLVd & $\mathrm{HLVd}+\mathrm{CBCVd}+\mathrm{HSVd}$ & $-6,66$ & $0,01^{\star}$ \\
\hline & $\mathrm{HLVd}+\mathrm{CBCVd}$ & HLVd+HSVd & 2,65 & 0,68 \\
\hline & $\mathrm{HLVd}+\mathrm{CBCVd}$ & $\mathrm{HLVd}+\mathrm{CBCVd}+\mathrm{HSVd}$ & 1,36 & 0,9 \\
\hline & HLVd+HSVd & $\mathrm{HLVd}+\mathrm{CBCVd}+\mathrm{HSVd}$ & $-1,95$ & 0,12 \\
\hline \multirow[t]{6}{*}{ CBCVd } & CBCVd & $\mathrm{HLVd}+\mathrm{CBCVd}$ & $-2,98$ & 0,88 \\
\hline & CBCVd & $\mathrm{CBCVd}+\mathrm{HSVd}$ & $-3,72$ & 0,12 \\
\hline & CBCVd & $\mathrm{HLVd}+\mathrm{CBCVd}+\mathrm{HSVd}$ & $-2,57$ & 0,97 \\
\hline & $\mathrm{HLVd}+\mathrm{CBCVd}$ & $\mathrm{CBCVd}+\mathrm{HSVd}$ & $-1,25$ & 0,77 \\
\hline & $\mathrm{HLVd}+\mathrm{CBCVd}$ & $\mathrm{HLVd}+\mathrm{CBCVd}+\mathrm{HSVd}$ & 1,16 & 0,1 \\
\hline & $\mathrm{CBCVd}+\mathrm{HSVd}$ & $\mathrm{HLVd}+\mathrm{CBCVd}+\mathrm{HSVd}$ & 1,45 & 0,59 \\
\hline \multirow[t]{6}{*}{ HSVd } & HSVd & HLVd+HSVd & $-10,83$ & $0,01^{\star}$ \\
\hline & HSVd & $\mathrm{CBCVd}+\mathrm{HSVd}$ & $-49,63$ & $<0,001^{\star * *}$ \\
\hline & HSVd & $\mathrm{HLVd}+\mathrm{CBCVd}+\mathrm{HSVd}$ & $-74,44$ & $<0,001^{\star * *}$ \\
\hline & HLVd+HSVd & $\mathrm{CBCVd}+\mathrm{HSVd}$ & $-4,58$ & $0,03^{\star}$ \\
\hline & HLVd+HSVd & $\mathrm{HLVd}+\mathrm{CBCVd}+\mathrm{HSVd}$ & $-6,88$ & $0,01^{\star}$ \\
\hline & $\mathrm{CBCVd}+\mathrm{HSVd}$ & $\mathrm{HLVd}+\mathrm{CBCVd}+\mathrm{HSVd}$ & $-1,5$ & 0,99 \\
\hline
\end{tabular}

Zvezdica $\left(^{*}\right)$ je standardni prikaz programa R oz. tudi nekaterih drugih programov za statistično obdelavo podatkov. Predstavlja vizualno vrednost, saj nam v tabeli p-vrednosti pomaga, da hitreje opazimo tiste vrednosti, ki so statistično značilne. Število * $(1,2$ ali 3$)$ je vezano na število decimalnih mest, kjer se pojavi številsko mesto. $0,01={ }^{*} ; 0,001={ }^{* *} ; 0={ }^{* * *}$

Asterisk $\left(^{*}\right)$ is a standard sign of $\mathrm{R}$ and other softwares for statistical analysis. It enables the user to quickly distinguish between the results that are either statistically significant or not. The number of ${ }^{*}(1,2$ or 3$)$ represents the number of decimal places before a numeric place 
stičnim testom EDGE (angl. empirycal analysis of DGE) (Robinson \& Smyth, 2008), ki je pokazal, da med vzorci ni statistično značilnih razlik na ravni kopičenja skupne količine viroidov. Ne glede na kombinacijo okužbe se viroidi razmnožijo do ravni zasičenja, kar kaže na omejeno biološko kapaciteto rastline. Opazimo tudi, da se med vzorci spreminja raven kopičenja posameznih viroidov. Tudi te razlike smo statistično ovrednotili, povzetek rezultatov pa je prikazan v Preglednici 3. Intervali na stolpcih predstavljajo standardne odklone in s tem biološko variabilnost med enakimi biološkimi obravnavanji.

Kot lahko vidimo iz Preglednice 3, so skoraj vse spremembe $\mathrm{v}$ akumulaciji posameznih viroidov negativne, a $\mathrm{v}$ nobenem primeru ne gre za statistično značilno zmanjšanje. Na podlagi teh podatkov ne moremo zaključiti, da je med viroidi prisoten antagonizem, čeprav obstaja velika verjetnost, da so molekule viroidov $\mathrm{v}$ medsebojnih interakcijah. Glede na znane podatke iz literature domnevamo, da je vanje vpleten tudi rastlinski mehanizem RNK interference (RNKi) kot obrambe proti dvoverižnim RNK molekulam (Rahman et al., 2008; Pokorn et al., 2017).

Graf na Sliki 2 prikazuje rezultate pridobljene $\mathrm{z}$ RT-qPCR metodo, kjer smo preverjali raven količine viroidov v rastlini. Stolpci in rumena linija predstavljajo povprečno raven akumulacije posameznih oz. vseh treh viroidov pri različnih bioloških obravnavanjih. Glede na to, da smo izvedli relativno kvantifikacijo ravni pomnoževanja viroidov tako, da smo izmerili vrednosti Cq tudi za referenčni gen DRH1 s konstantnim izražanjem, imajo vrednosti na y-osi enoto 1. Skupna količina viroidov (rumena linija) med posameznimi biološkimi obravnavanji bolj variira kot pri NGS rezultatih (Slika 1). Koefi- cient variacije pri NGS analizi je bil samo 0,05, medtem ko pri metodi RT-qPCR 0,66. Iz grafa na Sliki 2 opazimo tudi, da se skupna količina viroidov zmanjša, kadar primerjamo okužbe $\mathrm{s}$ posameznim viroidom $\mathrm{z}$ okužbami $\mathrm{z}$ dvema ali tremi viroidi. S testom ANOVA smo najprej preverili ali so razlike med skupno količino viroidov med različnimi biološkimi obravnavanji statistično značilne. Izkazalo se je, da je prisotna mejno statistično značilna razlika samo med biološkima obravnavama HSVd ter CBCVd in HSVd (na sliki 2 z oznako [3] in [6]), pri vrednosti $\mathrm{p}=0,0658$. Pri vseh ostalih parnih kombinacijah okužbe pa razlika v skupni količini viroidov tudi ni statistično značilna. Po drugi strani pa statističnih razlik ne potrdimo že zaradi velike variabilnosti med biološkimi ponovitvami, kar je razvidno iz prikazanih intervalov na posameznih stolpcih. Da bi podprli to razlago, da viroidi dosežejo nivo zasičenja $\mathrm{v}$ rastlini ne glede na kombinacijo okužbe, bi morali analizo izvesti ponovno in sicer tako, da bi najprej izmerili količine viroidov v vzorcih ter v nadaljnjo analizo vključili le tiste, ki imajo med seboj primerljive količine virodov. S statističnim tesom ANOVA smo preverili tudi, kako se med biološkimi obravnavanji spreminja nivo akumulacije posameznih viroidov. Povzetek rezultatov testa ANOVA je prikazan v Preglednici 4.

Iz rezultatov testa ANOVA (Preglednica 4) vidimo, da niso vse spremembe ravni akumulacije viroidov negativne. Prisotne so tudi pozitivne spremembe, ki so sicer bistveno manjše, niso pa statistično značilne. V nasprotju z rezultati testa EDGE, ki je temeljil na NGS podatkih (Preglednica 3) smo pri viroidu HLVd pokazali na statistično značilno zmanjšanje samo $\mathrm{v}$ primerjavi okužbe HLVd z okužbo z vsemi tremi viroidi (HLVd, CBCVd in

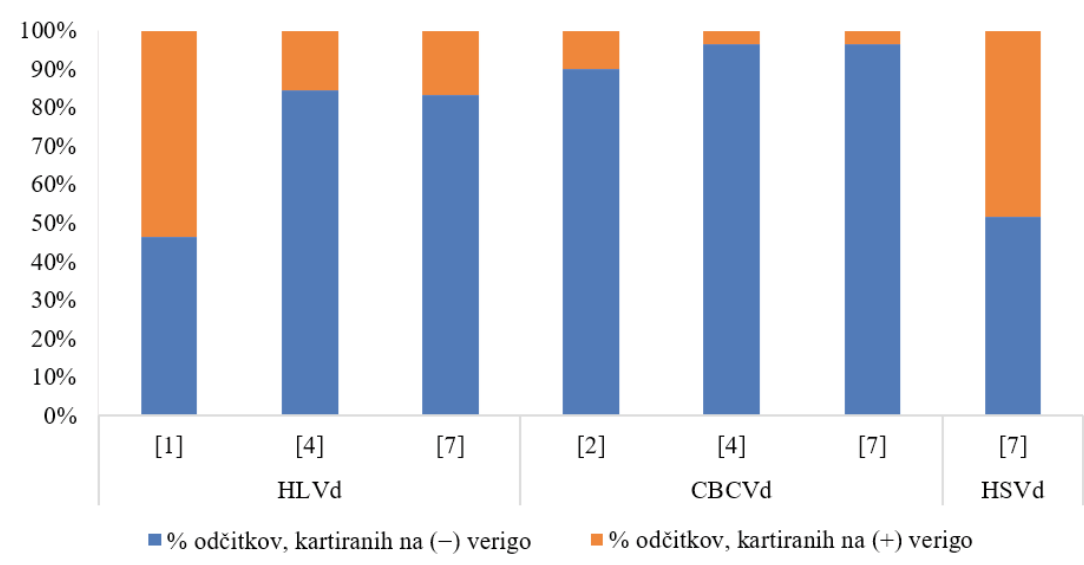

Slika 3: Odstotek odčitkov kartiranih na (-) in (+) verigo pripadajočega viroida pri različnih bioloških vzorcih na osnovi NGS analize. [1] = HLVd; [2] = CBCVd; [3] = HSVd; [4] = HLVd in CBCVd; [7] = HLVd, CBCVd in HSVd

Figure 3: NGS data indicating the percentage of reads mapped to either $(-)$ or $(+)$ strand of each viroid within different biological samples. [1] = HLVd; [2] = CBCVd; [3] = HSVd; [4] = HLVd and CBCVd; [7] = HLVd, CBCVd and HSVd 


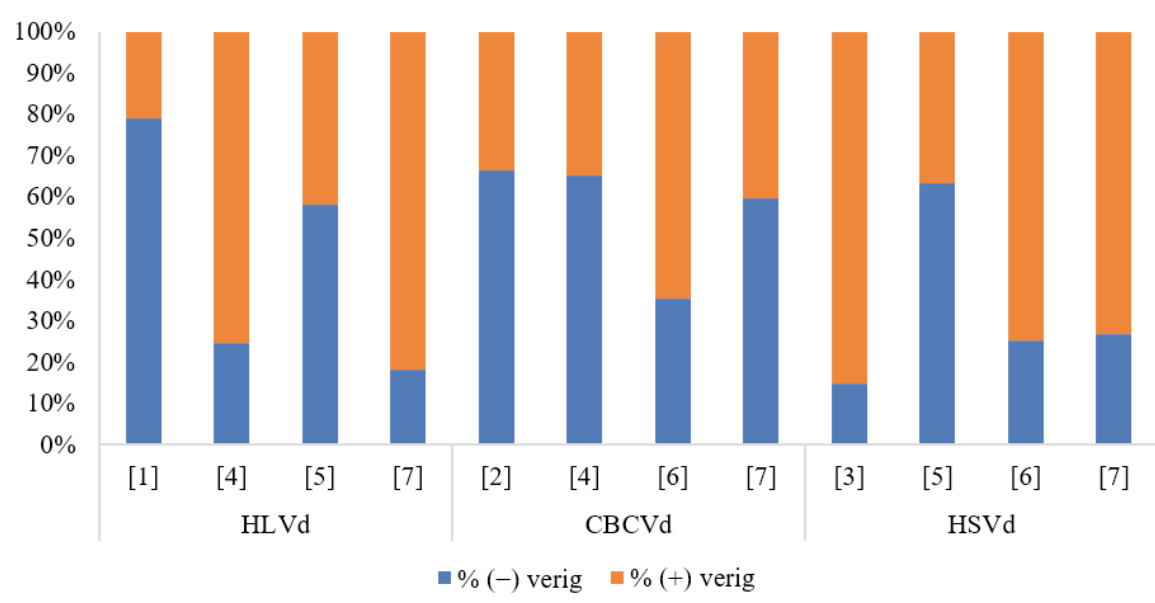

Slika 4: Odstotek (-) in (+) verig pripadajočih viroidov pri različnih bioloških vzorcih na osnovi RT-qPCR analize. [1] = HLVd; [2] = CBCVd; [3] = HSVd; [4] = HLVd in CBCVd; [5] = HLVd in HSVd; [6] = CBCVd in HSVd; [7] = HLVd, CBCVd in HSVd

Figure 4: RT-qPCR data indicating the percentage of either $(-)$ and $(+)$ strands of each viroid within different biological samples. [1] = HLVd; [2] = CBCVd; [3] = HSVd; [4] = HLVd and CBCVd; [5] = HLVd and HSVd; [6] = CBCVd and HSVd; [7] = HLVd, CBCVd and HSVd

HSVd). To je posledica antagonizma, saj so viroidi v isti ekološki niši in uporabljajo iste omejene vire rastline. Antagonizem pa v tem primeru nastopi šele, kadar so $\mathrm{v}$ hmelju prisotni vsi trije viroidi. Pri viroidu CBCVd v nobeni parni kombinaciji nismo potrdili statistično značilne razlike, kar kaže na to, da je ta viroid najmanj občutljiv na prisotnost drugih dveh in s tem najbolj uspešen antagonist, kar morda razlaga tudi njegovo simptomatsko agresivnost (Jakše et al., 2015). Podobno kot v primeru viroida HLVd smo pri viroidu HSVd v skoraj vseh parnih kombinacijah potrdili statistično značilno zmanjšanje, kar ponovno kaže na interferenco med viroidi. Izjema je primerjava biološkega obravnavanja $z$ viroidoma $\mathrm{CBCVd}$ in HSVd s trojno okužbo, kjer pa se raven akumulacije viroida HSVd praktično ne spremeni. Na podlagi tega sklepamo, da je viroid HSVd najbolj občutljiv, zlasti na viroid CBCVd.

Pri bioloških obravnavanjih s posameznim viroidom (na Sliki 2 z oznako [1], [2] in [3]) rezultati RT-qPCR kažejo, da je viroida HSVd največ, kar je zanimivo, saj je ta najmanj zastopan viroid v pridelavi hmelja v Sloveniji (Radišek et al., 2012). Glede na nekatere raziskave o medsebojnem vplivu patogenov v rastlini in podatke iz literature menimo, da igra rastlinska RNKi in ostali mehanizmi, ki vključujejo male RNK dinamično vlogo pri interakcijah med različnimi viroidi in hmeljem.

\subsection{POLARNOST MOLEKUL VIROIDOV}

Polarnost molekul nam med drugim podaja informacijo o aktivnosti podvojevanja viroidov $\mathrm{v}$ rastlinskih celicah. Pravzaprav prisotnost (-) oblik viroidov potrjuje aktivnost njihovega podvojevanja (Flores et al., 2017). Na Sliki 3 so prikazani sekvenčni odčitki, ki so se kartirali na $(-)$ oz. $(+)$ referenčne genome pripadajočih viroidov. Na podlagi tega lahko ocenimo razmerje med $(-)$ in $(+)$ polarnostjo molekul viroidov.

Iz Slike 3 najprej opazimo, da je v povprečju med vzorci razmerje med verigama pomaknjeno v smeri (-) verige, kar je zanimivo, saj je (+) veriga zrela oblika viroida in $(-)$ veriga matrica za njen nastanek (Flores et al., 2017). Kot rečeno (-) verige kažejo na aktivnost podvojevanja, iz česar bi sklepali, da se viroid CBCVd najbolj aktivno podvojuje pri vseh vzorcih. Naši podatki pa podpirajo tudi rezultate dela Matoušek et al. (2017), ki so prvi pokazali na povečano količino (-) verige viroida CBCVd v primerjavi s (+) verigo pri okuženem hmelju. Pri viroidu HLVd opazimo spremembo razmerja polarnosti, če primerjamo enojno okužbo z dvojno ali trojno, kar bi lahko bila posledica povečanja aktivnosti podvojevanja.

$\mathrm{Na}$ Sliki 4 so prikazani rezultati RT-qPCR, kjer smo pomnoževali specifično $(-)$ ali $(+)$ verige viroidov.

Razmerje verig najbolj variira pri viroidu HLVd, saj dva vzorca kažeta na večji delež (-) verig, dva pa na večji delež $(+)$ verig. Pri viroidih CBCVd in HSVd so trije od štirih vzorcev taki, ki kažejo na večjo količino ene od verig v primerjavi z drugo. Kar se tiče viroida CBCVd rezultati sovpadajo s podatki RNK sekvenciranja (Slika 3), čeprav (-) oblika ni tako močno prevladujoča nad (+) obliko. Rezultati kažejo, da metoda RT-qPCR ni najbolj ustrezna za tovrstni analizi, saj temelji na obratni transkripciji verig (Faggioli et al., 2017). Začetni oligonukle- 
otidi za prepis $(-)$ in $(+)$ pa tudi ne diskriminirajo med monomernimi in multimernimi enotami viroidov, kar doprinese $\mathrm{k}$ variabilnosti rezultatov tako pri analizi akumulacije, kot tudi pri polarnosti. Zanimivo je, da nekateri podatki iz literature (Dadami et al., 2017) kažejo, da je pri viroidnih okužbah količina (+) verige večja od (-) oz. da je slednjo celo zelo težko detektirati. Feldstein et al. (1998) so v svoji raziskavi pokazali tudi, da je (+) oblika viroida vretenatosti krompirjevih gomoljev (angl. potato spindle tuber viroid, PSTVd) infektivna oblika viroida, saj z (-) oblikami niso uspeli okužiti paradižnika, zaradi česar bi pričakovali, da bo prisotna večja količina $\mathrm{v}(+)$ obliki v primerjavi z (-) obliko. To se kaže le v primeru viroida HSVd, kjer so bili 3 izmed 4 vzorcev taki, kjer se je pomnožilo več $(+)$ kot (-) verig. Rastlinski obrambni sistem je morda bolj aktiven proti $(+)$ oblikam, saj (-) ne predstavljajo neposredne grožnje, kar bi pri viroidu CBCVd pojasnilo to, da je razmerje pomaknjeno v smeri (-) oblike. Znano je, da dvoverižna RNK v celici vzbudi proces RNKi, v kateri sodeluje več proteinov (Rahman et al., 2008). Med njimi so pomembne endonukleaze oz. proteini podobni proteinom »Dicer» (angl. dicer-like proteins), ki med drugim delujejo tudi na molekule viroidov, pri čemer nastajajo od viroidov pridobljene male RNK (angl. viroid derived sRNA, vd-sRNA). Ti proteini pa delujejo tako na zrele molekule viroidov kot tudi tudi na intermediate podvojevanja $(+)$ in $(-)$ polarnosti. Glede na to, da so viroidi kljub aktivirani RNKi še vedno prisotni, pomeni, da so nanjo vselej vsaj delno odporni (Dadami et al., 2017). Možnost nekonstantnosti (+) in (-) verig pri mešanih okužbah bi lahko bila posledica mešanih viroidnih okužb. Le-te so s stališča polarnosti verig zelo slabo raziskane.

\section{SKLEPI}

Raziskave hkratnih okužb rastlin $\mathrm{z}$ viroidi so $\mathrm{v}$ začetkih, zato naše delo predstavlja izhodišče za nadaljnje raziskovanje rastlinske virologije. V našem delu smo analizirali nivo pomnoževanja in polarnost molekul viroidov pri različnih kombinacijah okužb hmelja. Na podlagi podatkov RNK sekvenciranja smo pokazali, da se viroidi podvojujejo do ravni zasičenja, kar kaže na biološko kapaciteto rastline. Žal tega na podlagi rezultatov qPCR nismo potrdili zaradi prevelike variabilnosti med biološkimi ponovitvami. V nadaljevanju priporočamo izvedbo analize RT-qPCR, tako da najprej izmerimo količino viroidov v vzorcih, nato pa v nadaljevanju vključimo samo tiste s primerljivimi količinami. Zmanjšanje količine posameznih viroidov kaže na prisotnost antagonizma med viroidi. Molekularni mehanizmi antagonizma ostajajo še nepojasnjeni. Menimo, da viroidi pridejo $\mathrm{v}$ interferenco tudi preko rastlinskih obrambnih sistemov, še posebej RNKi. Rezultati qPCR nam kažejo, da je viroid CBCVd najmanj občutljiv, viroid HSVd pa najbolj na prisotnost drugih viroidov. V sklopu analize polarnosti molekul pa podatki RNK sekvenciranja kažejo, da je v povprečju (-) verige več kot $(+)$. Pri tem izstopa viroid CBCVd za katerega smo to potrdili tudi $\mathrm{z}$ analizo $\mathrm{RT}$-qPCR. $\mathrm{Za}$ viroida HLVd in HSVd pa je značilna večja nekonsistentnost kar se tiče razmerja med ( $(-)$ in (+) verigo, zaradi česar ostaja vprašanje polarnosti nepojasnjeno. $V$ literaturi pa tudi ni podatka o dolžini $(+)$ ali $(-)$ intermediatov med podvojevanjem viroida. Menimo, da bi bilo potrebno uporabiti alternativno metodo, ki ne temelji na obratni transkripciji, ampak na neposrednem štetju molekul RNK. Tak princip uporablja tehnologija sekvenciranja Nanopore (Feng et al., 2015), kjer je možno izjemno dolgim odčitkom določiti nukleotidno zaporedje $\mathrm{v}$ enem koraku. S to metodo bi v teoriji lahko tudi določili dolžino intermediatov viroidov, ki nastanejo med podvojevanjem in odgovorili na vprašanje koliko monomerov sestavlja en multimerni intermediat.

\section{ZAHVALA}

Delo je bilo omogočeno s finančno podporo Javne agencije za raziskovalno dejavnost Republike Slovenije (ARRS): programsko financiranje P4-0077 (Kmetijske rastline - genetika in sodobne tehnologije) in temeljni projekt L4-6809 (Analiza odziva rastlin ob hkratnih okužbah viroidov in identifikacija odpornosti).

\section{REFERENCE}

Barbara, D. J., \& Adams, A. N. (2003). Hop latent viroid. V: A. Hadidi, R. Flores, J. W. Randles, P. Palukaitis (Eds.), Viroids and Satelites (pp. 213-217). London, Academic Press.

Dadami, E., Dalakouras, A., Wassenegger, M. (2017). Viroids and RNA Silencing. V: A. Hadidi, R. Flores, J. W. Randles, P. Palukaitis (Eds.), Viroids and Satelites (pp. 115-124). London, Academic Press. https://doi.org/10.1016/B978-012-801498-1.00011-5

Diener, T. O. (1971). Potato Spindle Tuber »Virus« IV. A replicating, low molecular weight RNA. Virology, 45, 411-428. https://doi.org/10.1016/0042-6822(71)90342-4

Duran-Vila, N., \& Semancik, J. S. (2003). Citrus viroids. V: A. Hadidi, R. Flores, J. W. Randles, J. S. Semancik (Eds.), Viroids (pp. 178-194). Collingwood, Csiro Publishing.

Faggioli, F., Luigi, M., Boubourakas, I. N. (2017). Viroid Amplification Methods: RT-PCR, Real-Time RT-PCR and RT-LAMP. V: A. Hadidi, R. Flores, J. W. Randles, P. Palukaitis (Eds.), Viroids and Satelites (pp. 381-391). London, Academic Press. https://doi.org/10.1016/B978-0-12-8014981.00036-X 
Feldstein, P. A., Hu, Y., Owens, R. A. (1998). Precisely full length, circularizable, complementary RNA: an infectious form of potato spindle tuber viroid. Proceedings of the $\mathrm{Na}$ tional Academy of Sciences of the United States of America, 95(11), 6560-6565. https://doi.org/10.1073/pnas.95.11.6560

Feng, Y., Zhang, Y., Ying, C., Wang, D., Du, C. (2015). Nanopore-based Fourth-generation DNA Sequencing Technology. Genomics Proteomics Bioinformatics, 13(1), 4-16. https:// doi.org/10.1016/j.gpb.2015.01.009

Flores, R., Hernández, C., Emilio, Martínez de Alba A., Daròs, J. A., Di Serio, F. (2005). Viroids and viroid-host interactions. Annual Review of Phytopathology, 43, 117-139. https:// doi.org/10.1146/annurev.phyto.43.040204.140243

Flores, R., Minoia, S., López-Carrasco, A., Delgado, S., Martínez de Alba, A., Kalantidis, K. (2017). Viroid replication. V: A. Hadidi, R. Flores, J. W. Randles, P. Palukaitis (Eds.), Viroids and Satelites (pp. 71-81). London, Academic Press. https://doi.org/10.1016/B978-0-12-801498-1.00007-3

Góra-Sochacka, A. (2004). Viroids: unusual small pathogenic RNAs. Acta Biochimica Polonica, 51(3), 587-607. https:// doi.org/10.18388/abp.2004_3546

Jakše, J., Radišek, S., Pokorn, T., Matoušek, J., Javornik, B. (2015). Deep-sequencing revealed Citrus bark cracking viroid (CBCVd) as a highly aggressive pathogen on hop. Plant Pathology, 64, 831-842. https://doi.org/10.1111/ppa.12325

Kofalvi, S., A., José, F., M., Cañizares, M., C., Pallás, V., Candresse, T. (1997). Hop stunt viroid (HSVd) sequence variants from Prunus species: evidence for recombination between HSVd isolates. Journal of General Virology, 78(12), 3177-3186. https://doi.org/10.1099/0022-1317-78-12-3177

Matoušek, J., Siglová, K., Jakše, J., Radišek, S., Brass, J. R. J., Tsushima, T., ... Steger, G. (2017). Propagation and some physiological effects of Citrus bark cracking viroid and Apple fruit crinkle viroid in multiple infected hop (Humulus lupulus L.). Journal of Plant Physiology, 213, 166-177. https://doi.org/10.1016/j.jplph.2017.02.014

Mortazavi, A., Williams, B.A., McCue, K., Schaeffer, L., Wold, B. (2008). Mapping and quantifying mammalian transcrip- tomes by RNA-seq. Nature Methods, 5(7), 621-628. https:// doi.org/10.1038/nmeth.1226

Pfaffl, M., W. (2012). Quantification strategies in real-time polymerase chain reaction. V: Filion M. (Ed.), Quantitative Real-time PCR in Applied Microbiology (pp. 53-61). Norfolk, Caister Academic Press.

Pokorn, T., Radišek, S., Javornik, B., Štajner, N., Jakše, J. (2017). Development of hop transcriptome to support research into host-viroid interactions. Plos ONE, 12(9), e0184528. https://doi.org/10.1371/journal.pone.0184528

Puchta H., Ramm K., Sänger. 1988. The molecular structure of hop latent viroid (HLV), a new viroid occurring worldwide in hops. Nucleic Acids Research, 16(10), 4197-4216. https:// doi.org/10.1093/nar/16.10.4197

Radišek, S., Majer, A., Jakše, J., Javornik, B., Matoušek, J. (2012). First report of Hop stunt viroid infecting Hop in Slovenia. Plant disease, 96(4), 592-593. https://doi.org/10.1094/ PDIS-08-11-0640-PDN

Rahman, M., Ali, I., Husnian, T., Riazuddin, S. (2008). RNA interference: The story of gene silencing in plants and humans. Biotechnology Advances, 26(3), 202-209.Robinson, M. D., Smyth, G. K. (2008). Small-sample estimation of negative binomial dispersion with applications to SAGE data. Biostatistics, 9(2), 321-332. https://doi.org/10.1016/j. biotechadv.2007.12.002

Sasaki, M., \& Shikata, E. (1977). On some properties of hop stunt disease agent, a viroid. Proceedings of the Japan Academy, Series B, 53, 109-112. https://doi.org/10.2183/ pjab.53.109

Steger G., \& Riesner, D. (2003). Molecular characteristics. V: A. Hadidi, R. Flores, J. W. Randles, J. S. Semancik (Eds.), Viroids (pp. 15-29). Collingwood, Csiro Publishing.

Štajner, N., Cregeen, S., Javornik, B. (2013). Evaluation of reference genes for RT-qPCR expression studies in Hop $(\mathrm{Hu}$ mulus lupulus L.) during infection with vascular pathogen Verticillium albo-atrum. PLos One, 8(7), e68228, https:// doi.org/10.1371/journal.pone.0068228. 